\title{
A Pengaruh Kepemimpinan dan Pengembangan Karir Terhadap Niat untuk Tinggal dengan Keterikatan Kerja sebagai Intervening
}

The Influence of Leadership and Career Development on the Intention to Stay with Work Engagement as an Intervening

\section{Kriswanta Simon; Ari Mulyono2; Hery Iskandar3; Faisal Haris Pratama4; Dwi Wiji Astuti5; Alafta Aulia6}

Info:

Received:

05 Jan 2021

Review:

21 Jan 2021

Accepted:

06 Feb 2021

Online:

08 Feb 2021

\section{Abstrak}

Penelitian bertujuan menguji pengaruh kepemimpinan dan pengembangan karir pada perusahaan penggilingan baja di kabupaten Bekasi terhadap niat untuk tinggal dengan keterikatan kerja sebagai intervening. Data diperoleh dari kuesioner yang diberikan kepada 61 karyawan. Pendekatan yang dilakukan adalah dengan penelitian kuantitatif dengan analisis struktural menggunakan Smart PLS 3. Penelitian menemukan bahwa pengembangan karir berpengaruh terhadap keterikatan kerja dan ikut mempengaruhi niat untuk tinggal. Kepemimpinan tidak berpengaruh terhadap keterikatan kerja dan niat untuk tinggal, tetapi hal ini perlu menjadi perhatian khusus bagi perusahaan.

Kata Kunci: Pengembangan karir, kepemimpinan, keterikatan kerja, niat untuk tinggal Kode JEL:

This study aims to examine the influence of leadership and career development in steel milling companies in Bekasi district on the intention to stay with work engagement as an intervening. Data obtained from questionnaires given to 61 employees. The approach taken is quantitative research with structural analysis using Smart PLS 3. The study found that career development affects work engagement and also influences the intention to stay. The leadership does not affect work engagement and the intention to stay, but this needs special attention for the company.

Keywords: Career Development, Leadership, Work Engagement, Intention to Stay

JEL Codes: .....

How to cite:

Simon, K., Mulyono, A., Iskandar, H., Pratama, F.H., Astuti, D.W., Aulia, A., (2021). Pengaruh Kepemimpinan dan Pengembangan Karir Terhadap Niat untuk Tinggal dengan Keterikatan Kerja sebagai Intervening. Master: Jurnal Manajemen Strategik Kewirausahaan, 1(01), Th.. doi: https://doi.org/10.37366/master.v1i1.135

\section{Pendahuluan}

SDM dalam suatu perusahaan merupakan hal yang sangat vital. Keberhasilan, keberlangsungan dan segala aktivitas organisasi bergantung pada sumber daya manusia. Perubahan teknologi, sosial politik dan budaya, dan pasar, menuntut perusahaan untuk berbenah dalam pengelolaan dan pengembangan SDM. SDM dituntut semakin mampu menangkap fenomena perubahan, menganalisa dampaknya bagi organsasi dan menyiapkan langkah-langkah untuk menghadapi kondisi melalui inovasi dan improvement. Perubahan

\footnotetext{
${ }_{1}$ Prodi MM, FEBIS, Universitas Pelita Bangsa; skriswanta@gmail.com

2 Prodi MM, FEBIS, Universitas Pelita Bangsa; arimulyono@gmail.com

${ }_{3}^{3}$ Prodi MM, FEBIS, Universitas Pelita Bangsa; herliiskandar@gmail.com

4 Prodi MM, FEBIS, Universitas Pelita Bangsa; Faisalharispratama@gmail.com

${ }^{5}$ Prodi MM, FEBIS, Universitas Pelita Bangsa; dwiwijiastuti@gmail.com

6 Prodi MM, FEBIS, Universitas Pelita Bangsa; alaftaaulia@gmail.com
} 
kultur gen generasi juga menjadi salah satu pemicu perubahan perilaku organisasi. Generasi millenial yang sangat menyukai teknologi, fleksibilitas, kecepatan dan kebebasan menyisakan peluang masalah jika salah dalam pengelolaannya yaitu turnover.

Permasalahan turnover saat ini menjadi permasalahan di setiap perusahaan. Kondisi yang sama juga terjadi pada perusahaan penggilingan baja di bekasi yang berdiri sejak 2013 dengan 100\% sahamnya milik Jepang. Perussahaan ini memiliki problem pengelolaan SDM. Data departemen sumberdaya manusia perusahaan menunjukkan bahwa sejak 2015 sampai 2017, nilai turnover karyawan melebihi target maksimal perusahaan (5\%).Pada periode tersebut turnover karyawan sampai mencapai 7-10\%.

Kepindahan karyawan merugikan perusahaan apalagi jika karyawan yang pindah adalah karyawan potensial. Kepindahan karyawan dapat menyebabkan terhentinya kegiatan sehingga produktivitas menurun yang tentu saja merugikan perusahaan. Oleh karena itu faktor yang mempengaruhi turnover perlu digali oleh perusahaan agar dapat mengambil tindakan preventif untuk menurunkannya. Kepindahan karyawan dapat dicegah selama kepindahan tersebut masih pada tahap niat (turnover intention). Keinginan berpindah kerja dapat terjadi karena lingkungan kerja, pengembangan karir, penghargaan, dan peran dalam bekerja di organisasi (Nafiudin, 2017). Selain itu, turnover intention dapat dipengaruhi oleh pengembangan karir, kepuasan kerja, keterikatan kerja, kepemimpinan, remunerasi (gaji), budaya organisasi dan karakteristik pekerja (Saklit, 2017).

Karir merupakan salah satu faktor yang penting dalam mempengaruhi niat karyawan untuk berpindah. Karyawan yang karirnya berkembang cenderung tidak memiliki niat untuk mencari pekerjaan lain apalagi keluar dari perusahaan (Nafiudin, 2017). Ada juga temuan yang menunjukkan bahwa pengembangan karir tidak mempengaruhi intensi turnover (Saklit, 2017). Inkonsistensi hasil penelitian tersebut yang menjadi landasan pentingnya penelitian ini. Penyesuaian dilakukan dimana penelitian melihat dari sisi positif dimana yang diteliti bukan niat berpindahnya melainkan niat untuk tetap tinggal (intention to stay) sebagaimana yang dilakukan penelitian sebelumnya (Sanjeevkumar, 2012; Fransiska, 2014). Perhatian pada intention to stay dilakukan karena niat tetap tinggal berarti karyawan masih berada di organisasi sehingga perusahaan dapat berupaya untuk mempertahankan karyawan potensial yang dikehendaki.

Penelitian ini tetap mengangkat pengembangan karir tetapi dikaitkan dengan keinginan untuk tinggal (intention to stay) (Fransiska, 2014) bukan terhadap turnover intention (Nafiudin, 2017). Penelitin ini juga mengisi kesenjangan tidak adanya pengaruh pengembangan karir terhadap intention to stay (Saklit, 2017) dengan menambahkan keterikatan karyawan pada pekerjaan atau perusahaan (engagement) sebagai variabel intervening. Pengembangan karir yang dirancang secara baik untuk membantu meningkatkan kualitas kehidupan karyawan mampu mempertahankan karyawan potensial untuk tetap tinggal (Dayona dan Rinawati, 2016; Fitria dan Kuwara, 2019; Rayvina dan Drahen, 2014). Karyawan yang terikat dengan pekerjaan yang pada akhirnya akan memiliki niat yang kuat untuk tetap tinggal di organisasi (Sanjeevkumar, 2012; Kemie dan Purba, 2019).

Pengembangan karir akan lebih efektif mendorong keterikatan karyawan jika dibarengi dengan kepemimpinan yang baik (Riama dan Dhaen, 2013). Kepemimpinan menjadi hal kunci yang mampu menjaga marwah organisasi untuk memastikan strategi organisasi berjalan dengan baik dan menjaga karyawan untuk tetap bertahan. Kepemimpinan yang efektif terbukti memberikan efek positif terhadap keterlibatan 
karyawan di Perusahaan sebagaimana penelitian sebelumnya (Riama \& Dhaen, 2013) pada sebuah Rumah Sakit di Kabupaten Bekasi yang menunjukkan bahwa kepemimpinan yang efektif dari level puncak mampu mengikat karyawan untut tetap bertahan, karena dinilai memberikan kenyamanan, keamanan dan keharmonisan hubungan kerja dalam organisasi. Hal serupa dibuktikan dalam penelitian di PT Kusumaputra Santosa yang menunjukkan bahwa secara statsistik kepemimpinan memberikan pengaruh positif terhadap keterikatan kerja karyawan (Agus, 2015). Keterikatan kerja sendiri terlihat dalam perilaku karyawan untuk tetap tinggal di Akademi Teknik Cikarang-Bekasi yang secara positif terbukti dipengaruhi oleh variabel kepemimpinan (Kemie dan Purba, 2019).

Niat untuk tinggal (intention to stay) menjadi begitu penting sehingga perusahaan harus dengan cepat perlu tau apa yang menjadi penyebabnya. Semakin tingginya karyawan merasa tidak betah atau sampai memutuskan keluar (resign) akan merugikan perusahaan baik secara materiil ataupun non materiil. Penelitian ini memasukkan keterikatan kerja yang menjembatani pengambangan karir dan kepemimpinan dalam menjaga karyaan untuk tetap tinggal. Fokus penelitian ini ada pada bagaimana kepemimpinan dan pengembangan karir mampu mengikat karyawan untuk tinggal dalam organisasi.

\section{Metodologi}

\section{Pengembangan Model}

\section{Keterikatan dan Keinginan Tinggal}

Keterikatan merupakan salah satu akibat dari adanya sesuatu yang mengikat sebagai alasan seseorang untuk loyal atau ketergantungan dengan hal itu. Demikian juga keterikatan karyawan, dimana selalu ada hal-hal yang menjadi alasan karyawan untuk lebih loyal ke perusahaan/organisasi, pekerjaan itu sendiri ataupun melakukan hal yang lebih untuk perusahaan. Alasan atau hal yang sering kali dirasa menguntungkan bagi karyawan sebagai isu utama adalah perihal apa yang dia terima (remunerasi), pertumbuhan/perkembangan individu (karir), kenyamanan dalam bekerja (pekerjaan-atasan-rekan kerja ataupun lingkungan). Perusahaan yang mampu mengakomodir hal-hal tersebut, maka karyawan akan merasa di hargai, keberadaannya diakui, kontribusinya diberikan apresiasi, nyaman untuk berekspresi, aman (proteksi) tentang pendapatan/fasilitas /jaminan pensiun atau hak-hak yang dapat dibawa pulang (Kemie dan Purba, 2019). Karyawan yang sudah merasa ada ikatan dengan pekerjaan/perusahaan, maka karyawan merasa tidak ada pilihan untuk keluar dan tidak berfikir untuk mencari peluang lain (Sanjeevkumar, 2012; Kemie dan Purba, 2019; Fauzia dan Marwansyah, 2020) serta akan tumbuh semangat untuk melakukan lebih untuk perusahaan (karena merasa memiliki). Kemungkinan keputusan untuk tetap tinggal dalam organisasi menjadi pilihan utama. Karyawan akan melakukan lebih untuk perusahaan karena merasa memiliki/turut bertanggungjawab akan kelangsungan perusahaan. Keterikatan untuk tetap tinggal bisa dicapai ketika karyawan merasa nyaman, aman, hubungan kerja yang harmonis dan bisa berkembang di Perusahaan (Riama \& Dhaen, 2013).

\section{H1: Keterikatan berpengarub terhadap keinginan tinggal}

\section{Kepemimpinan, Keterikatan dan Keinginan Tinggal}

Keberadaan pemimpin sering menjadi perbincangan di kalangan karyawan. Karyawan merasa nyaman jika pemimpinnya itu baik, peduli, memutuskan/menentukan 
kebijakan/peraturan yang tidak merugikan karyawan serta memiliki orientasi visi ke depan terutama tentang pengembangan karyawannya (Riama \& Dhaen, 2013). Hal ini sangat dimungkinkan, karena pemimpin merupakan individu yang dapat menentukan kesemuanya itu. Pemimpin yang arogan, tidak care, tidak cakap dalam mengatur/mengelola dan menentukan strategi perusahaan, tidak dapat menjadi contoh karyawan, atau tidak mampu menciptakan kondisi perusahaan yang nyaman, juga dimungkinkan akan mempengaruhi perilaku karyawan. Potensi adanya ketidaknyamanan itu dapat berdampak pada ikatan emosional, loyalitas karyawan terhadap perusahaan dan munculnya pemikiran untuk pindah perusahaan. Kepemimpinan yang baik akan memberikan rasa nyaman dan perasaan ikut dilibatkan dalam proses, sehingga karyawan merasa memiliki tanggungjawab yang sama akan kelangsungan organisasi atau memberikan efek positif bagi keterikatan kerja (Agus, 2015; Riama dan Dhaen, 2013). Karyawan yang sudah memiliki keterikatan dengan pekerjaan atau perusahaan karena merasa mendapat perhatian dari pimpinan akan memiliki niat kuat untuk bertahan di perusahaan (Sanjeevkumar, 2012; Kemie dan Purba, 2019; Fauzia dan Marwansyah, 2020).

H2: Kepemimpinan berpengarub terhadap keterikatan

\section{H3: Kepemimpinan berpengarub terhadap keinginan tinggal melalui keterikatan}

\section{Pengembangan Karir, Keterikatan, Keinginan Tinggal}

Karyawan bekerja selain mencari uang dan pengalaman juga mencari/mengupayakan untuk terus berkembang. Tetapi belum tentu semua ekspektasi itu dapat tercapai. Terutama dalam hal berkembang, karena bisa tergantung pada bagaimana perusahaan itu memiliki aturan mainnya. Karyawan secara naluri ingin dirinya dapat tumbuh, berkembang disuatu tempat dengan apapun yang telah diupayakan/dilakukannya di perusahaan. Peluang berkembangnya karyawan secara individu dalam sebuah perusahaan dapat menjadi ruang adanya daya tarik yang mampu memberi tawaran atau bahkan mengikat karyawan untuk tetap tinggal dan loyal ke Perusahaan. Pengembangan karir bisa dilihat dari bagaimana Perusahaan memiliki kebijakan orientasi pada tumbuh kembangnya karyawan, baik melalui pelatihan, pengembangan ilmu pengetahuan/keterampilan yang disesuaikan dengan kebutuhan karyawan dalam mempermudahnya saat bekerja (Fitria \& Kuwara, 2019). Pengembangan karir melalui pelatihan, pembelajaran pengetahuan/ keterampilan baru yang sesuai kebutuhan kerja mampu meningkatkan Engagement karyawan (Dayona dan Rinawati, 2016; Rayvina dan Drahen, 2014).

H4: Pengembangan karir berpengaruh terhadap keterikatan

\section{H5: Pengembangan karir berpengaruh terhadap keinginan tinggal melalui keterikatan}

Pengembangan model yang memunculkan hipotesis, memunculkan medel penelitian dimana terdapat pengaruh kepemimpinan dan pengembangan karir terhadap keterikatan kerja, serta Keterikatan kerja terhadap keinginan tinggal. Penelitian dilakukan untuk menjawab gap penelitian terdahulu bahwa pengembangan karir tidak ada hubungannya dengan turnover yang dalam penelitian ini dinilai dari sisi yang lain yaitu intention to stay. Pada model penelitian ini ditambahkan variabel keterikatan kerja menjadi hal yang paling memungkinkan digunakan untuk mengetahui sekaligus menjembatani gap penelitian tersebut. Adapun indikator setiap Variabelnya dapat dilihat dari table 1. 


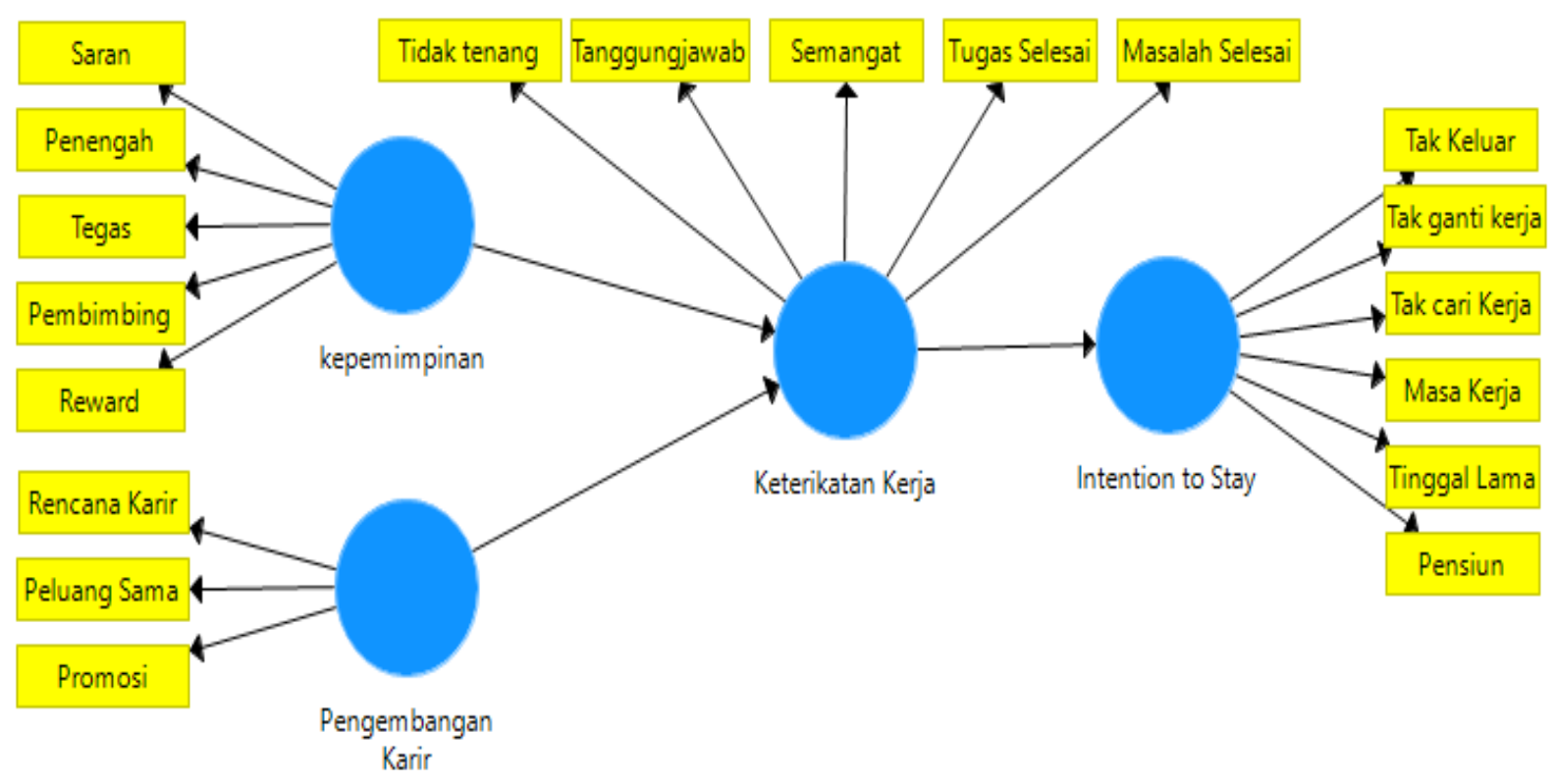

Sumber: Pengolaban Samrt PLS 3 (2021)

Gambar 1. Kerangka Konsep

Tabel 1. Operasional Variabel

\begin{tabular}{|c|c|c|}
\hline Variabel & Indikator & Skala \\
\hline $\begin{array}{l}\text { Kepemimpinan } \\
\text { (Riama \& Dhaen, } \\
\text { 2013) }\end{array}$ & $\begin{array}{l}\text { Pemimpin memberi saran } \\
\text { Pemimpin menjadi penengah } \\
\text { Pemimpin memiliki ketegasan } \\
\text { Pemimpin membimbing } \\
\text { Pemimpin memberikan reward yang sesuai }\end{array}$ & Interval 1-5 \\
\hline $\begin{array}{l}\text { Pengembangan Karir } \\
\text { (Fitria \& Kuwara, } \\
\text { 2019). }\end{array}$ & $\begin{array}{l}\text { Perencanaan Karir jelas } \\
\text { Karyawan memiliki peluang karir yang sama } \\
\text { Karyawan memiliki peluang karir yang sama } \\
\text { Karyawan memiliki peluang sama dalam promosi }\end{array}$ & Interval 1-5 \\
\hline $\begin{array}{l}\text { Keterikatan Kerja } \\
\text { (Kemie dan Purba, } \\
\text { 2019) }\end{array}$ & $\begin{array}{l}\text { Perasaan tidak tenang meninggalkan pekerjaan } \\
\text { Tanggungjawab tinggi } \\
\text { Memiliki Semangat yang tinggi } \\
\text { Selalu berupaya menyelesaikan tugas } \\
\text { Selalu menyelesaikan masalah }\end{array}$ & Interval 1-5 \\
\hline $\begin{array}{l}\text { Niat untuk tetap } \\
\text { Tinggal. } \\
\text { (Kemie dan Purba, } \\
\text { 2019) }\end{array}$ & $\begin{array}{l}\text { Tidak ingin keluar } \\
\text { Tidak ingin ganti pekerjan } \\
\text { Tidak ingin cari pekerjaan } \\
\text { Ingin tinggal dalam waktu lama } \\
\text { Ingin bekerja sampai pensiun }\end{array}$ & Interval 1-5 \\
\hline
\end{tabular}

Sumber: Pengolahan Samrt PLS 3 (2021)

\section{Pengumpulan Data}

Penelitian dilakukan pada perusahan yang bergerak di penggilingan baja di kabupaten Bekasi. Pendekatan penelitian ini dengan penelitian kuantitatif melalui kuesioner yang 
disebarkan sebagai data primer. Kuesioner menggunakan interval nilai 1-5 sebagai alat pengumpulan data untuk mengambarkan penilaian responden dari penilaian sangat tidak setuju sampai sangat setuju.

Pengumpulan data melalui google form secara acak (sampling) selama 2 minggu untuk penarikan data. Kuesioner yang tersebar dan telah kembali, diisi oleh 61 Responden. Data yang telah dikumpulkan tersebut kemudian diolah menggunakan Smart PLS 3.

\section{Metode Analisis}

Langkah-langkah menganalisa data yang masuk, peneliti menggunakan software Smart PLS 3.0, hal ini dilakukan karena jumlah Respondennya kurang dari 100 (sedikit). Langkah pertama dengan melakukan pengujian validitas data, reliabilitas data, uji Model dan Uji Hipotesis. Pada langkah pengujian validitas data menjadi keharusan sebelum dilakukan pengujian selanjutnya, karena peneliti harus menguji terlebih dahulu, apakah alat ukurnya sudah sesuai dengan hal yang akan diuji, ketepatan alat ukur menjadi hal kunci akan keberhasilan pengujian. Langkah selanjutnya dengan pengujian Reliabilitas data untuk menguji konsistensi alat yang digunakan, konsisten atau tidak jika dilakukan pengulangan di waktu atau tempat yang lain, atau sejauh mana alat itu dapat dipercaya dan diandalkan.

Pengujian validitas dan reliabilitas data dengan software Smart PLS 3. Validitas data menggunakan critical value Outer Loading 0,7 dengan dan AVE 0,6. Pengujian reliablitias data dengan menggunakan nilai Cronbach's Alpha dan Composite Reliability. Reliabilitas harus menghasilkan nilai Cronbach's Alpha dan Composite Reliability diatas 0.70. (Priyanto, 2016). Langkah selanjutnya jika data yang diuji sudah valid dan reliabel, adalah melakukan pengujian konstruksi. Pada pengujian ini peneliti melihat nilai R-Square, dimana nilai R-Square nilainya adalah 0.2 yang dilihat dari variabel keterikatan kerja dan keinginan tinggal. Jika nilai R-Squarenya 0.2 maka konstruksi model ini sudah benar, baru dapat dilakukan pengujian Hipotesis dengan menggunakan nilai estimate dan p-value.

Pengujian hipotesis dengan uji t yaitu dengan melihat nilai koefisien dengan nilai signifikansi 0.05. Nilai probabilitas $\mathrm{t}>0.05$ maka tidak signifikan, sedangkan nilai probabilitas $t<0.05$ maka signifikan (Kemie dan Purba, 2019)

Selanjutnya melakukan pengujian secara parsial baik langsung maupun tidak langsung terhadap 2 model persamaan yang ada yaitu:

$\mathrm{Y}=\varrho \mathrm{YX} 1+\varrho \mathrm{YX} 2+\varepsilon 1$ substruktur 1

$\mathrm{Z}=\varrho Z \mathrm{ZX} 1+\varrho Z \mathrm{ZX} 2+\varrho Z \mathrm{ZY}+\varepsilon 2$ substruktur 2

Menghitung Pengaruh langsung (direct effect):

Pengaruh Kepemimpinan $\left(\mathrm{X}_{1}\right)$ terhadap Keterikatan Kerja $\left.(\mathrm{Y}): \mathrm{DE}_{\mathrm{X} 1 \mathrm{Y}}=\mathrm{X}_{1} \rightarrow \mathrm{Y} \ldots \ldots .3\right)$

Pengaruh Pengembangan Karir $\left(\mathrm{X}_{2}\right)$ terhadap Keterikatan Kerja $(\mathrm{Y})$ :

$\mathrm{DE}_{\mathrm{X} 2 \mathrm{Y}}=\mathrm{X} 2 \rightarrow \mathrm{Y}$

Pengaruh Keterikatan Kerja $(Y)$ terhadap Keinginan tinggal $\left.(\mathrm{Z}): \mathrm{DE}_{Y Z}=\mathrm{Y} \rightarrow \mathrm{Z} \ldots \ldots . .5\right)$ Menghitung pengaruh tidak langsung (indirect effect):

Pengaruh tidak langsung Kepemimpinan $\left(\mathrm{X}_{1}\right)$ terhadap Keinginan tinggal $(\mathrm{Z})$ melalui Keterikatan Kerja (Y) :

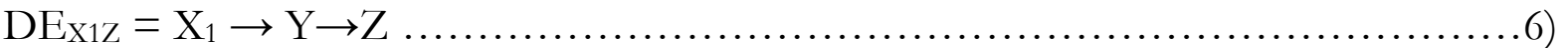

Pengaruh tidak langsung Pengembangan Karir $\left(\mathrm{X}_{2}\right)$ terhadap Keinginan tinggal $(\mathrm{Z})$ melalui Keterikatan Kerja $(\mathrm{Y}):$

$\mathrm{DE}_{\mathrm{X} 2 \mathrm{Z}}=\mathrm{X}_{2} \rightarrow \mathrm{Y} \rightarrow \mathrm{Z}$ 


\section{Hasil}

\section{Responden}

Responden yang dijadikan objek penelitian sebanyak 61 responden yang terdiri dari laki-laki 48 orang dan perempuan 13 orang. Latar belakang pendidikan SMA 19 orang, D3 22 orang dan S1 20 orang. Usia masing-masing kurang dari 25 tahun 15 orang, 25-40 tahun 44 orang dan usia lebih dari 40 tahun 2 orang, dari level Operator sampai Manager.

\section{Pengujian Instrumen}

Tabel 2 menunjukkan seluruh instrumen telah valid dan reliabel atau dapat diandalkan atau konsisten. Valid karena outer loading pada seluruh indikator lebih besar dari atau mendekati 0,7 dan AVE pada masing-masing variabel lebih besar dari 0,6. Reliabilitas terpenuhi karena cronbach's alpha dan composite reliability pada setiap variabel telah lebih besar dari 0,7.

Tabel 2. Uji Validitas Data

\begin{tabular}{|c|c|c|c|c|c|}
\hline Indikator & $\begin{array}{c}\text { Outer } \\
\text { Loading }\end{array}$ & AVE & $\begin{array}{c}\text { Cronbach } \\
\text { Alpha }\end{array}$ & $\begin{array}{l}\text { Composite } \\
\text { Reliability }\end{array}$ & Keterangan \\
\hline$\overline{\text { Kepemimpinan (X1) }}$ & - & 0.673 & 0.879 & 0.912 & Reliabel \\
\hline - Saran & 0.827 & & & & Valid \\
\hline - Penengah & 0.820 & & & & Valid \\
\hline - Tegas & 0.824 & & & & Valid \\
\hline - Pembimbing & 0.832 & & & & Valid \\
\hline - Reward (penghargaan) & 0.799 & & & & Valid \\
\hline Pengembangan Karir (X2) & - & 0.916 & 0.954 & 0.970 & Reliabel \\
\hline - Peluang Sama & 0.961 & & & & Valid \\
\hline - Rencana Karir & 0.967 & & & & Valid \\
\hline - Promosi & 0.942 & & & & Valid \\
\hline Keterikatan Kerja (Y) & - & 0.595 & 0.829 & 0.879 & Reliabel \\
\hline - Tidak tenang tinggalkan pekerjaan & 0.681 & & & & Valid \\
\hline - Tanggungjawab & 0.880 & & & & Valid \\
\hline - Semangat & 0.812 & & & & Valid \\
\hline - Menyelesaikan tugas & 0.681 & & & & Valid \\
\hline - Menyelesaikan Masalah & 0.785 & & & & Valid \\
\hline Keinginan Tinggal (Z) & - & 0.768 & 0.941 & 0.952 & Reliabel \\
\hline - Tidak ingin keluar & 0.886 & & & & Valid \\
\hline - Tidak ingin ganti pekerjaan & 0.746 & & & & Valid \\
\hline - Tidak ingin cari kerja & 0.884 & & & & Valid \\
\hline - Ingin menghabiskan masa kerja & 0.920 & & & & Valid \\
\hline - Ingin tinggal lama & 0.900 & & & & Valid \\
\hline - Sampai Pensiun & 0.911 & & & & Valid \\
\hline
\end{tabular}

Sumber: Pengolahan Samrt PLS 3 (2021) 


\section{Uji Konstruk Model}

Tabel 3 menunjukkan Outer Loading - R Square lebih besar atau sama dengan 0.200 untuk tiap variabel yang dipengaruhi. Dengan demikian dapat disimpulkan bahwa model yang terbentuk dikategorikan model baik.

Tabel 3. R Square

\begin{tabular}{lcc}
\hline \multicolumn{1}{c}{ Variabel Endogen } & R Square & Kategori \\
\hline Keterikatan & 0.200 & Baik \\
Keinginan Tinggal & 0.380 & Sangat Baik \\
\hline
\end{tabular}

Sumber: Pengolahan Smart PLS 3 (2021)

\section{Estimasi dan Uji Hipotesis}

Tabel 4 menunjukkan hasil penelitian dimana dari lima hipotesis terdapat tiga hipotesis yang diterima dan dua hipotesis yang ditolak. Hipotesis pertama menunjukkan bahwa penambahan variabel keterikatan terbukti mempengaruhi niat untuk tinggal. Hipotesis kedua dan ketiga menunjukkan bahwa keterikatan tidak sebagai intervening antara kepemimpinan dan keinginan tinggal. Hipotesis keempat dan kelima membuktikan keterikatan sebagai intervening antara pengembangan karir dengan keinginan tinggal.

Tabel 4. Uji T

\begin{tabular}{|c|c|c|c|c|c|}
\hline ALur & Estimasi & P Value & $\mathrm{t}$ & Keterar & ngan \\
\hline $\begin{array}{l}\text { Keterikatan kerja } \rightarrow \text { keinginan } \\
\text { tinggal }\end{array}$ & 0.464 & 0.000 & 5.670 & Signifikan & H1: diterima \\
\hline $\begin{array}{l}\text { Kepemimpinan } \rightarrow \text { keterikatan } \\
\text { kerja }\end{array}$ & 0.273 & 0.116 & 1.575 & Tidak Signifikan & H2: ditolak \\
\hline $\begin{array}{l}\text { Kepemimpinan } \rightarrow \text { keterikatan } \rightarrow \\
\text { keinginan tinggal }\end{array}$ & 0.130 & 0.168 & 1.381 & Tidak Signifikan & H3: ditolak \\
\hline $\begin{array}{l}\text { Pengembangan karir } \rightarrow \\
\text { keterikatan kerja }\end{array}$ & 0.395 & 0.007 & 2.688 & Signifikan & H4: diterima \\
\hline $\begin{array}{l}\text { Pengembangan karir } \rightarrow \\
\text { keterikatan } \rightarrow \text { keinginan tinggal }\end{array}$ & 0.180 & 0.010 & 2.572 & Signifikan & H5: diterima \\
\hline
\end{tabular}

Sumber: Pengolahan Samrt PLS 3 (2021)

\section{Pembahasan}

\section{Pengaruh Keterikatan Kerja terhadap Keinginan tinggal}

Keterikatan kerja berpengaruh terhadap keinginan tinggal dengan arah positif $(0,464)$. Karyawan merasa tidak nyaman jika terlalu lama meninggalkan pekerjaan, bertanggungjawab atas tugasnya, memiliki semangat tinggi menyelesaikan masalah merupakan tanda danya keterikatan kerja. Karyawan yang memiliki keterikatan yang tinggi dan tidak ingin keluar dari perusahaan.

Penelitian ini sejalan dengan temuan penelitian sebelumnya (Sanjeevkumar, 2012; Kemie dan Purba, 2019; Fauzia dan Marwansyah, 2020) dengan temuan bahwa karyawan yang terikat dengan pekerjaan atau perusahaan akan enggan meninggalkan pekerjaan atau 
perusahaan untuk mencari pekerjaan lain. Makin tinggi keterikatan yang dimiliki akan makin tinggi niat untuk tetap tinggal diperusahaan. Oleh karena perlu mendorong karyawan untuk memiliki perasaan tidak tenang meninggalkan pekerjaan, tanggungjawab, semangat menyelesaikan tugas dan menyelesaikan masalah.

\section{Pengaruh Kepemimpinan terhadap Keterikatan Kerja dan Keinginan tinggal}

Kepemimpinan tidak mempengaruhi keterikatan kerja. Meskipun keterikatan kerja mempengaruhi keinginan untuk tetap tinggal tetapi kepemimpinan tidak dapat mempengaruhi niat karyawan untuk tinggal. Hal ini menunjukkan bahwa kepemimpinan yang dijalankan perusahaan selama ini belum mampu mendorong niat karyawan untuk tetap bertahan.

Hasil penelitian ini tidak sejalan dengan temuan yang pernah ada (Agus, 2015; Riama dan Dhaen, 2013) yang temuannya justru kepemimpinan memegang peran penting untuk menjaga karyawan agar tetap tinggal bekerja di perusahaan. Kepemimpinan yang efektif mampu memberikan rasa nyaman kepada karyawan sehingga membuat karyawan lebih bertahan dalam perusahaan dan memberikan pengaruh positif terhadap keterikatan kerja. Temuan penelitian ini menyisakan pertanyaan yang perlu dijawab pada penelitian selanjutnya.

\section{Pengaruh Pengembangan Karir terhadap Keterikatan Kerja dan Keinginan tinggal}

Pengembangan karir mempengaruhi keterikatan kerja secara positif $(0,395)$. Pengembangan karir juga mempengaruhi keinginan tinggal karena memiliki keterikatan dengan pekerjaan $(0,180)$. Pengembangan Karir yang dilakukan dengan memberikan kesempatan yang sama untuk berkembang, merencanakan karir melalui pelatihan dan promosi jabatan sesuai kecakapan dan prestasi kerja telah terbukti membuat karyawan merasa terikat yang pada akhirnya akan meningkatkan keinginan untuk tetap tinggal.

Penelitian tidak sejalan dengan temuan sebelumnya (Rayvina \& Drahen, 2014) pengembangan karir yang terdiri dari kecapakan, pendidikan formal, prestasi kerja tidak berpengaruh besar pada keterikatan kerja. Penelitian ini berbeda dengan temuan sebelumnya (Saklit, 2017) yang menyatakan pengembangan karir tidak serta merta menurunkan perputaran karyawan.

Penelitian ini sejalan dengan penelitian sebelumnya (Dayona dan Rinawati, 2016; Fitria dan Kuwara, 2019; Rayvina dan Drahen, 2014) dimana pengembangan karir mempengaruhi niat untuk tinggal. Penelitian ini sekaligus membuktikan bahwa keterikatan kerja memediasi pengaruh pengembangan karir terhadap niat tetap tingal. Oleh karena itu pengembangan karir perlu mendapat perhatian dari perusahaan yang menginginkan karyawannya tetap tinggal dan tidak mencari pekerjaan atau profesi lain.

\section{Kesimpulan}

Kepemimpinan tidak mempengaruhi keterikatan dan niat untuk tinggal. Sedangkan pengembangan karir yang baik akan mendorong kuatnya keterikatan karyawan dengan pekerjaannya sehingga berdampak pada niat untuk tetap tinggal. Hal ini membuktikan keberadaan keterikatan kerja sebagai intervening bagi pengembangan karir terhadap niat tetap tinggal tapi di sebagai intervening bagi kepemimpinan. 
Penelitian ini menyisakan pertanyaan dengan tidak adanya pengaruh kepemimpinan terhadap keterikatan dan kepemimpinan terhadap niat untuk tinggal melalui keterikatan. Oleh karena itu diharapkan ada penelitian lanjutan tentang kepemimpinan dalam kaitannya dengan keterikatan kerja.

\section{Daftar Pustaka}

Agus, S. (2015). Keterkaitan Kepemimpinan Transformasional, Makna Kerja, Karakteriktik Penguji dan Keterlibatan Kerja di Kusumaputra Santosa Karanganyar. Perpustakaan.Uns.Ac.Id, 1-15.

Dayona, G., \& Rinawati, N. (Mei-Agustus 2016). Pengaruh Pelatihan dan Pengembangan Karir Terhadap Employee Engagement di Pt Andalan Finance Indonesia. Jurnal Indonesia Membangun,Vol. 15, No. 2. ISSN : 1412-6907, 39-62.

Fauzia, N.K. dan Marwansyah. (2020), Pengaruh Employee Engagement terhadap Turnover Intention Studi Kasus PT XYZ Bandung, Jurnal Riset Bisnis dan Investasi, Vol. 6, No. 1, April 2020, p. 33-42., P-ISSN 2460-8211 E-ISSN 2684-706X

Fitria, D., \& Kuwara, R. (2019). Pengaruh Pengembangan Karir dan Kepuasan Kerja Terhadap Employee Engagement Di Pt Klx Bekasi. Jurnal Ilmiah Akuntansi Dan Manajemen (JLAM), Vol.15, No.2, November 2019, ISSN 0216-7832, 63-69.

Fransiska, Y. (2014). Pengaruh Human Resources Management Practice Terhadap Employee Intention To Stay pada Pt Media Nusantara Informasi (Sindo). Jurnal Manajemen. Vol 11 No 2 November 2014, 57 - 72.

Kemie, S.S., Purba, S.D. (2019). Efek Miediasi Kepuasan Kerja Pada Pengaruh Keterikatan Kerja dan Manajemen Karir Terhadap Keinginan Untuk Tetap Tinggal di dalam organisasi. Jurnal Ekonomi-Manajemen-Akuntansi Volume 15, Nomor 1, April 2019., Hal 177-194.

Nafiudin. (2017). Analisis turnover Intention Karyawan Generasi Y Di Provinsi Banten Serta Faktor Yang Mempengaruhinya. Jurnal Penelitian Ekonomi Dan Bisnis,2(1), Hal: 1 -9.

Rayvina, R., \& Drahen, P. (2014). Pengaruh Pengembangan Karir Pada Employee Engagement PT Bukakak Teknik Utama Unit Jembatan. Administrasi Negara, 1-16.

Riama, E., \& Dhaen, P. (2013). Pengaruh Kepemimpinan Terhadap Keterikatan Karyawan Tetap Non Manajerial Di RS XYZ . Administrasi Negara, 1-16.

Saklit, W. (2017). Pengaruh Gaya Kepemimpinan Dan Pengembangan Karir Terhadap Intensi Turnover: Kepuasan Kerja Sebagai Mediator. Jurnal Manajemen/Volume XXI, No. 03,, 472 490.

Sanjeevkumar, V. (2012). A Study On Employee's Intention To Stay In Public Companies, Kedah, Malaysia. Zenith International Journal Of Business Economics \& Management Research, Vol.2 Issue 4, April2012, ISSN 2249 8826, 91-101. 